\title{
Combining Ability in Relation to Wheat (Triticum aestivum L.) Breeding Programme under Heat Stress Environment
}

\author{
Sanjeev Kumar ${ }^{1 *}$, S.K. Singh ${ }^{1}$, S. K. Gupta ${ }^{1}$, Vishwanath $^{1}$, Prashant $\operatorname{Yadav}^{2}$, \\ Surendra Kumar ${ }^{1}$, Jaydev Kumar ${ }^{1}$, H.N. Bind ${ }^{3}$ and Lokendra Singh ${ }^{1}$ \\ ${ }^{1}$ Department of Genetics and Plant Breeding, Chandra Shekhar Azad University of Agriculture \\ and Technology, Kanpur 208002, Uttar Pradesh, India \\ ${ }^{2}$ ICAR-Indian Agricultural Research Institute, New Delhi 110012, India \\ ${ }^{3}$ Department of Genetics and Plant Breeding, Sardar Vallabhbhai Patel University of Agriculture \\ and Technology, Meerut 250110, Uttar Pradesh, India \\ *Corresponding author
}

A B S T R A C T

Keywords

Wheat, General combining ability, Specific combining ability.

Article Info

Accepted:

26 September 2017

Available Online:

10 October 2017
A set of 45 crosses were generated by crossing 10 lines viz., K9533, K9162, K9465, K8962, HUW234, NW2036, K9423, K9351, KRL210 and K906 following half diallel design of wheat under late sown condition. Ten parents, $45 \mathrm{~F}_{1}$ hybrids and $45 \mathrm{~F}_{2}$ populations using Randomized Block Design with three replications were evaluated for yield and other important morpho-physiological characters at Kanpur (UP, India). General combining ability (GCA) and specific combining ability (SCA) for maturity and yield components traits were determined. The main objective of the research was the identification and proper selection of best performing wheat parental genotypes and best $\mathrm{F}_{1}$ crosses, based on GCA and SCA estimates under heat stress environment. Significant differences were observed among the wheat genotypes for all the studied traits. The estimates of $\sigma 2 \mathrm{GCA}$ and $\sigma 2 \mathrm{SCA}$ and its ratio $(\sigma 2 \mathrm{GCA} / \sigma 2 \mathrm{SCA})$ indicated that non-additive genetic expression was a pre-dominant for most of traits studied. K9533, K906, K9351 and K9423 were good general combiners for most of the traits under consideration, while $F_{1}$ hybrids and $\mathrm{F}_{2}$ populations K9465 x K9351, K9162 x K906, NW2036 x K9351, K9162 x K8962 and HUW234 x KRL210 were best specific combiners observed for several important traits including grain yield plant-1 which can be subsequently utilized in future wheat breeding to develop high yielding new wheat cultivars from transgressive segregants recovered in latter generations.

\section{Introduction}

Wheat (Triticum aestivum L.) cultivation reaches far back into history. It is one of the oldest domesticated grain crops and since then it has been the basic staple food of different civilizations of Europe, West Asia, and North Africa. The total cultivated area of wheat in India for the cropping year 2016-17 was $9.75 \mathrm{~m}$ hectares, with the total wheat produce of 96.64 million tonnes and average grain yield of $2989 \mathrm{Kg} \mathrm{ha}^{-1}$ (Anonymous 2016-17). As a staple food crop, wheat is fulfilling the calorie demands of growing population. It is only behind the pulses for the protein content (Kandhare, 2014). The main 
focus is on to increase wheat production and to break the yield stagnancy from last decades. This has been in response to the pressure for an adequate food supply caused by constantly increasing population in India and the world in general. Wheat cultivars that can withstand abiotic stresses particularly terminal heat tolerance will be able to fulfill the food demand in coming years Iqbal et al., (2017). Therefore, development of new improved wheat cultivars with high genetic potential for yield under stress environment has become a major objective in the wheat breeding.

For improvement in wheat yield, the study of the genetic structure and trend of combining ability and plant behavior under heat stress is of great importance for the wheat scientist, knowledge of general and specific combining ability along with the mode of gene action in the available breeding material is very important to start the effective wheat breeding programme. Half diallel mating is an effective strategy to evaluate genotypes used as parents for combining ability effects in order to select suitable parents for developing new cultivars Hayman (1954a, b) and Jinks (1954). Many researchers have studied the combining ability and genetic structure of bread wheat hybrid populations using half diallel mating method related to yield and yield components. Several researchers like Sprague and Tatum (1942); Griffing (1956 a), have reported that majority of genetic variances of grain yield as well as yield components are under control of nonadditive nature of genes. However, Zahid et al., (2008) have reported that numbers of tillers plant- 1 are controlled by additive gene action.

This study was undertaken to find out good combining ability for important yield contributing traits for a heat stress condition, so that superior cross combination are selected for development of new cultivars with desirable attributes.

\section{Materials and Methods}

An experiment was conducted at Crop Research Farm, Nawabganj, C. S. Azad University of Agriculture and Technology, Kanpur- 208 002. (U.P.) during Rabi, 201213. Experimental material for present investigation comprised of $45 \mathrm{~F}_{1}{ }_{1}^{\mathrm{s}}$ developed by crossing 10 lines viz., K-9533, K9162, K9465, K8962, HUW234, NW2036, K9423, K9351, KRL210 and K906 following half diallel design. A total of 100 treatments and 10 parents $\left(45 \mathrm{~F}_{1}\right.$ 's and $45 \mathrm{~F}_{2}$ 's) were used for the study of combining ability for eighteen quantitative characters in wheat. The $F_{1}$ hybrids and $F_{2}$ generation along with their parents were evaluated during the cropping year 2012-13 using Randomized Block Design with three replications in late sown (LS) condition.

The entries were sown in a single row plot of $3 \mathrm{~m}$ length with inter and intra-row spacing of $23 \mathrm{~cm}$ and $18 \mathrm{~cm}$, respectively. Data were taken on maturity, morphological and yield parameters namely, leaf angle, chlorophyll fluorescences, canopy temperature depression, chlorophyll intensity and grain yield plant -1. Analysis of variance was performed by the formula of Fisher (1918) to determine the significant differences among wheat genotypes. Combining ability analysis was carried out by the method of Kempthorne (1957).

\section{Results and Discussion}

Analysis of variance (Table 1) for combining ability, revealed highly significant variance for both general and specific combining ability in both the generations for all the characters, indicating the importance of both additive and non-additive gene action in the expression of these traits. However, the additive variance was predominant for all the characters in both generations having higher values. 
The GCA and SCA effects as per perusal of results (Table 1) were highly significant for all the characters in both the generations. The magnitudes of SCA variances were higher than GCA for all characters in both the generation except leaf angle. However, in few cases, the reliability has a question due to the expression of hybrid vigor among the progenies of parental crosses and could not be treated as best general combiners.

Thus, under such situations when the character is controlled unidirectionally by a set of allele and additive effects were important then parents might be more effective. The genetic variance of $F_{1}$ generation was more than $\mathrm{F}_{2}$ for all the traits except in few cases under this study. Similar performance was observed due to GCA/ SCA ratio as indicated for that $F_{1}$ values were higher than the $F_{2}$ values in respect of all the attributing traits except canopy temperature depression and days to physiological maturity a predominant role of additive gene action and non-additive gene action in $F_{1}$ and $F_{2}$ generations respectively (Siddique et al., 2004).

The estimates of GCA effects and corresponding mean performance of the parents along with succeeding generations for days to anthesis were most effective due to the parent K8962, HUW234 and K9351; for specific leaf weight due to K9533, K9351 and K906; leaf angle due to K9533, K9162, K8962, and K9423 having maintaining metabolic activities in system a sustainable manner; NW2036 and K9423, for chlorophyll florescences; K906, K9423, K9351 and HUW234 for canopy temperature depression; K9423, K9351 and KRL210 for chlorophyll intensity; NW2036, K9351 and K906 for increased flag leaf area of main shoot; K9533, K8962 and HUW234 for decrease in days to physiological maturity; The grain yield per plant, K9423, K9351 and K906 were most considerable due to their highly productive nature. It indicated that these parents in a future breeding programme might be most effective in improvement of quality traits.

In most of the cases, if the character is unidirectionally controlled by a set of alleles with predominant additive effects, the section of parents on the basis of per se performance may be adequate (Tables 4 and 5). Other researchers were also in agreement of this conclusion that some phenotypically superior line may yield poor recombinants in segregating populations (Yadav and Murty, 1976 and Singh et al., 1990). It is, therefore, essential that the parents should be selected on the basis of their combining ability estimates.

The diversity of origin of parents combined with additive $\mathrm{x}$ additive interaction effects is likely to give better recombinants in their cross combinations with high yield on the advancement of generation. Genetic diversity within a population can be an appropriate compromise between the demands for uniformity and advantage of diversity (Allard and Hansche, 1964). Generally for an autogamous crop like wheat, a study of segregating population for specific combining ability (SCA) would be important. In the present study, the SCA effects in both the generations (Table 3) were most outstanding. The estimated value of SCA effects for a desirable trait like days to anthesis in both the generations involving combination, K $9351 \mathrm{x}$ KRL 210 was favorable for earliness. The estimated value of SCA effects for chlorophyll fluorescences in K 9162 x NW 2036, K 8962 x K 906, K 9465 x KRL 210, K $9533 \times \mathrm{K} 9351$ and $\mathrm{K} 9533 \times \mathrm{K} 9162$ in $\mathrm{F}_{1}$ and K 9162 x NW 2036, K 9465 x KRL 210, K 8962 x K 906 and KRL 210 x K 906 and K $9533 \times \mathrm{K} 9162$ crosses of $\mathrm{F}_{2}$ generation were most considerable higher value of chlorophyll fluorescence indicated that good health of PSII thereby generation of more ATP which later utilize in $\mathrm{CO}_{2}$ reduction via process of 
photosynthesis. A similar finding was reported by Balouhi (2010) and Shahbazi et al., (2012). For canopy temperature depression in 9465 x KRL 210, K 9162 x K 906, K 9423 x KRL 210. HUW 234 x NW 2036 and HUW $234 \times \mathrm{K} 9351$ in $\mathrm{F}_{1}$ and $\mathrm{K}$ 9465 x K 9351, K 9423 x KRL 210, K 9162 x
K 906, HUW 234 x KRL 210 and HUW 234 $x$ NW 2036 crosses of $F_{2}$ generation were most considerable at higher canopy temperature depression proved to be more heat tolerant. Similar findings were observed by (Mohammadi et al., 2012).

Table.1 Weather data recorded at Nawabganj during the crop season 2012-13

\begin{tabular}{|c|c|c|c|c|c|c|c|}
\hline \multirow{2}{*}{$\begin{array}{l}\text { Met. } \\
\text { weeks }\end{array}$} & \multirow{2}{*}{$\begin{array}{l}\text { Standard } \\
\text { weeks }\end{array}$} & \multicolumn{2}{|c|}{ Temperature $\left({ }^{0} \mathrm{C}\right)$} & \multicolumn{2}{|c|}{$\begin{array}{c}\text { Average relative } \\
\text { humidity (\%) }\end{array}$} & \multirow{2}{*}{$\begin{array}{c}\text { Total } \\
\text { Rainfall } \\
(\mathbf{m m})\end{array}$} & \multirow{2}{*}{$\begin{array}{c}\text { Sunshine } \\
\text { (hrs) }\end{array}$} \\
\hline & & Min. & Max. & Min. & Max. & & \\
\hline 49 & 3-9 Dec & 8.5 & 26.5 & 36 & 76 & 00.0 & 7.7 \\
\hline 50 & $10-16$ & 9.7 & 25.9 & 55 & 93 & 00.0 & 5.5 \\
\hline 51 & $17-23$ & 8.0 & 20.2 & 61 & 87 & 00.0 & 5.7 \\
\hline 52 & $24-31$ & 4.4 & 15.6 & 71 & 96 & 00.0 & 0.8 \\
\hline 1 & 1-7Jan & 3.0 & 14.3 & 67 & 95 & 00.0 & 2.1 \\
\hline 2 & $8-14$ & 3.7 & 21.1 & 52 & 90 & 00.0 & 4.4 \\
\hline 3 & $15-21$ & 9.4 & 21.9 & 90 & 93 & 00.0 & 2.9 \\
\hline 4 & $22-28$ & 5.4 & 19.9 & 61 & 92 & 00.0 & 5.9 \\
\hline 5 & 29-4 Feb & 6.8 & 23.0 & 56 & 89 & 00.0 & 4.9 \\
\hline 6 & $5-11$ & 10.0 & 22.3 & 65 & 92 & 00.0 & 5.9 \\
\hline 7 & $12-18$ & 10.5 & 21.7 & 69 & 93 & 00.0 & 5.7 \\
\hline 8 & $19-25$ & 10.9 & 24.7 & 69 & 92 & 00.0 & 7.4 \\
\hline 9 & 26-4 Mar & 11.7 & 26.3 & 57 & 89 & 00.0 & 9.4 \\
\hline 10 & 5-11 & 12.5 & 30.0 & 44 & 87 & 00.0 & 9.8 \\
\hline 11 & $12-18$ & 14.5 & 30.4 & 41 & 80 & 00.0 & 8.6 \\
\hline 12 & $19-25$ & 15.9 & 33.1 & 45 & 79 & 00.0 & 8.2 \\
\hline 13 & 26-1April & 15.5 & 31.9 & 42 & 82 & 00.0 & 8.3 \\
\hline 14 & $2-8$ & 17.3 & 36.2 & 26 & 56 & 00.0 & 9.7 \\
\hline 15 & $9-15$ & 18.7 & 38.4 & 26 & 54 & 00.0 & 7.9 \\
\hline 16 & $16-22$ & 18.5 & 35.1 & 36 & 60 & 00.0 & 6.5 \\
\hline
\end{tabular}

Source: Department of Agro-meteorology C. S. Azad University of Agriculture and Technology, Kanpur

Table.2 Feature of genotype used in a 10 parental diallel mating design in wheat (Triticum aestivum L. em. Thell)

\begin{tabular}{|c|c|c|c|c|c|}
\hline S. No. & Genotype & Species & Pedigree & Production Condition & Place of origin \\
\hline 1 & K9533 & T. aestivum & HI1077/HUW234 & Irrigated, late sown & CSA, Kanpur \\
\hline 2 & K9162 & T. aestivum & K7827/HD2204 & Irrigated, late sown & CSA, Kanpur \\
\hline 3 & K9465 & T. aestivum & B1153/CB85 & Late sown, rainfed & CSA, Kanpur \\
\hline 4 & K8962 & T. aestivum & K7401/HD2160 & Rained, timely sown & CSA, Kanpur \\
\hline 5 & HUW234 & T. aestivum & HUW-21*2/CPAN1666 & Irrigated, late sown & BHU, Varanasi \\
\hline 6 & NW2036 & T. aestivum & BOW/CROW//BUC/PVN & Irrigated, late sown & NDUAT Faizabad \\
\hline 7 & K9423 & T. aestivum & HP1633/KSONA/UP262 & $\begin{array}{c}\text { High fertility, irrigated } \\
\text { and very late sown }\end{array}$ & CSA, Kanpur \\
\hline 8 & K9351 & T. aestivum & K72/K8077//K72 & Rained, timely sown & CSA, Kanpur \\
\hline 9 & KRL210 & T. aestivum & PBW65/2*PASTOR & Irrigated, timely sown & CSSRI, Karnal \\
\hline 10 & K906@ & T. aestivum & UP2338/PBW373 & Irrigated, late sown & CSA, Kanpur \\
\hline
\end{tabular}

(C) check variety 
Table.4 Ranking of the desirable parents on the basis of per se performance and GCA effects for five characters in bread wheat

\begin{tabular}{|c|c|c|c|c|c|}
\hline \multirow{2}{*}{ Character } & \multirow{2}{*}{$\begin{array}{c}\text { Desirable parent on the } \\
\text { basis of per se } \\
\text { performance }\end{array}$} & \multicolumn{2}{|c|}{ Good general combiner } & \multirow{2}{*}{$\begin{array}{c}\text { Common parent in } \\
F_{1} \text { and } F_{2}\end{array}$} & \multirow{2}{*}{$\begin{array}{c}\text { Common parent on the } \\
\text { basis of per se and gca } \\
\text { effect in } F_{1} \text { and } F_{2}\end{array}$} \\
\hline & & $\mathbf{F}_{1}$ & $\mathbf{F}_{2}$ & & \\
\hline Leaf Angle & $\begin{array}{c}\text { K9162 } \\
\text { K9533 } \\
\text { K8962 } \\
\text { HUW234 } \\
\text { K9351 } \\
\end{array}$ & $\begin{array}{l}\text { K8962** } \\
\text { K9533** } \\
\text { K9423** } \\
\text { K9162** } \\
\text { K903** }\end{array}$ & $\begin{array}{l}\text { K8962** } \\
\text { K9533** } \\
\text { K9423** } \\
\text { K9162** } \\
\text { K9351** }\end{array}$ & $\begin{array}{l}\text { K8962 } \\
\text { K9533 } \\
\text { K9423 } \\
\text { K9162 }\end{array}$ & $\begin{array}{l}\text { K8962 } \\
\text { K9533 } \\
\text { K9162 }\end{array}$ \\
\hline $\begin{array}{l}\text { Chlorophyll } \\
\text { florescence }\end{array}$ & $\begin{array}{l}\text { K8962 } \\
\text { K9351 } \\
\text { K9423 } \\
\text { K9162 } \\
\text { K9533 } \\
\end{array}$ & $\begin{array}{c}\text { NW203** } \\
\text { K9423** } \\
\text { K9351** } \\
\text { K8964** } \\
\text { K9162** } \\
\end{array}$ & $\begin{array}{c}\text { K9533** } \\
\text { K906** } \\
\text { K9423** } \\
\text { HUW234** } \\
\text { NW2036** } \\
\end{array}$ & $\begin{array}{c}\text { K9423 } \\
\text { NW2036 }\end{array}$ & K9423 \\
\hline $\begin{array}{l}\text { Canopy temperature } \\
\text { depression }\end{array}$ & $\begin{array}{c}\text { K9533 } \\
\text { K9162 } \\
\text { K9465 } \\
\text { NW2036 } \\
\text { K906 } \\
\end{array}$ & $\begin{array}{c}\text { K906** } \\
\text { K9423** } \\
\text { K9351** } \\
\text { HUW234** }\end{array}$ & $\begin{array}{c}\text { K906** } \\
\text { K9423** } \\
\text { K9351** } \\
\text { HUW234** }\end{array}$ & $\begin{array}{c}\text { K906 } \\
\text { K9423 } \\
\text { K9351 } \\
\text { HUW234 }\end{array}$ & K906 \\
\hline Chlorophyll intensity & $\begin{array}{c}\text { K9162 } \\
\text { KRL210 } \\
\text { K906 } \\
\text { NW2036 } \\
\text { K9533 }\end{array}$ & $\begin{array}{l}\text { K9423** } \\
\text { K906** } \\
\text { KRL21** } \\
\text { K9351** }\end{array}$ & $\begin{array}{c}\text { K9423** } \\
\text { K9351** } \\
\text { HUW234** } \\
\text { K9162** } \\
\text { KRL210** }\end{array}$ & $\begin{array}{c}\text { K9423 } \\
\text { KRL210 } \\
\text { K9351 }\end{array}$ & KRL210 \\
\hline $\begin{array}{l}\text { No. of grain yield } \\
\text { plant-1 }\end{array}$ & $\begin{array}{c}\text { K9162 } \\
\text { K9423 } \\
\text { K9533 } \\
\text { K906 } \\
\text { KRL2140 }\end{array}$ & $\begin{array}{l}\mathrm{K} 9351 * * \\
\mathrm{~K} 906 * * \\
\mathrm{~K} 9423 * *\end{array}$ & $\begin{array}{c}\text { K906** } \\
\text { K9351** } \\
\text { K9423** }\end{array}$ & $\begin{array}{c}\text { K906 } \\
\text { K9351 } \\
\text { K9423 }\end{array}$ & $\begin{array}{c}\text { K906 } \\
\text { K9423 }\end{array}$ \\
\hline
\end{tabular}

* Significance at $5 \%$ probability level, $* *$ Significance at $1 \%$ probability level 
Table.5 Ranking of the cross in respect to their superiority for specific combining ability, per se performance and general combining ability effect of the parent for five charters in bread wheat

\begin{tabular}{|c|c|c|c|}
\hline \multirow[t]{2}{*}{ Charters } & \multicolumn{2}{|c|}{ Good specific combiner } & \multirow{2}{*}{$\begin{array}{l}\text { Superior cross on the basis of per se } \\
\text { performance }\end{array}$} \\
\hline & $\mathbf{F}_{1}$ & $\mathbf{F}_{2}$ & \\
\hline Leaf angle & $\begin{array}{l}\text { K9533 x KRL210, HUW234 x NW2036, } \\
\text { K9533 x NW2036, K9162 x k8962 and } \\
\text { HUW324 x K9423 }\end{array}$ & $\begin{array}{l}\text { K9162 x KRL210, K9533 x } \\
\text { NW2036, HUW324 x K9423, } \\
\text { HUW234 x NW2036 and K8962 } \\
\text { x KRL210 }\end{array}$ & $\begin{array}{l}\text { K9533 x KRL210, K9533 x NW2036, } \\
\text { K9533 x K9423, K9162 x K8962 and } \\
\text { K8962 x KRL210 }\end{array}$ \\
\hline $\begin{array}{l}\text { Chlorophyll } \\
\text { fluorescences }\end{array}$ & $\begin{array}{l}\text { K } 9162 \text { x NW 2036, K } 8962 \text { x K 906, K } \\
9465 \text { x KRL 210, K } 9533 \text { x K } 9351 \text { and } \\
\text { K } 9533 \text { x K } 9162\end{array}$ & $\begin{array}{l}\text { K } 9162 \text { x NW 2036, K } 9465 \text { x } \\
\text { KRL 210, K } 8962 \text { x K } 906 \text { and } \\
\text { KRL } 210 \text { x K } 906 \text { and K } 9533 \text { x } \\
\text { K } 9162\end{array}$ & $\begin{array}{l}\text { K9162 x NW2036, K8962 x K906, } \\
\text { K8962 x K906, K9533 x K9351, } \\
\text { K9533 x K9162 and K9465 x KRL210 }\end{array}$ \\
\hline $\begin{array}{l}\text { Canopy temperature } \\
\text { depression }\end{array}$ & $\begin{array}{l}9465 \text { x KRL 210, K } 9162 \text { x K 906, K } \\
9423 \text { x KRL 210. HUW } 234 \text { x NW } 2036 \\
\text { and HUW } 234 \text { x K } 9351\end{array}$ & $\begin{array}{l}\text { K } 9465 \text { x K 9351, K } 9423 \text { x } \\
\text { KRL 210, K } 9162 \text { x K 906, } \\
\text { HUW } 234 \text { x KRL } 210 \text { and HUW } \\
234 \text { x NW } 2036\end{array}$ & $\begin{array}{l}\text { K9465 x K9351, K9162 x K906, } \\
\text { K9423 x K906, K9423 x KRL210 and } \\
\text { HUW234 x K906 }\end{array}$ \\
\hline Chlorophyll intensity & $\begin{array}{l}\text { HUW } 234 \text { x K 9423, NW } 2036 \text { x K } \\
\text { 9351, K } 9465 \text { x K 9351, K } 9465 \text { x KRL } \\
210 \text { and K } 9162 \text { x K } 902\end{array}$ & $\begin{array}{l}\text { NW } 2036 \text { x K 9351, HVW } 234 \\
\text { x K 9423, K } 9485 \text { x K 9351, K } \\
9423 \text { x K9351 and K } 9162 \text { x K } \\
906\end{array}$ & $\begin{array}{l}\text { HUW234 x K9423, NW2036 x K9351, } \\
\text { K9465 x K9351, K9162 x K906, } \\
\text { K9423 x KRL210 }\end{array}$ \\
\hline $\begin{array}{l}\text { No. of grain yield } \\
\text { plant-1 }\end{array}$ & $\begin{array}{l}\text { K } 9465 \text { x K 9351, K } 9162 \text { x K 906, K } \\
9465 \text { x KRL 210, HUW } 234 \text { x KRL } \\
210, N W 2036 \text { x K } 9351\end{array}$ & $\begin{array}{l}\text { K 9465 x K 9351, K 9162 x K } \\
\text { 906, K 9465 x KRL 210, K } 9162 \\
\text { X K 8962, K } 8962 \text { x KRL } 210\end{array}$ & $\begin{array}{l}\text { K9465 x K9351, K9162 x K906, } \\
\text { NW2036 x K9351, K9162 x K8962, } \\
\text { HUW234 x KRL210 }\end{array}$ \\
\hline
\end{tabular}


Table.3 Analysis of variance for combining ability for five attributes in a 10 parent diallel cross in F1 and F2 generation of wheat (Triticum aestivum L.): Mean sum of squares

(Griffings Method 2 Model I)

\begin{tabular}{|c|c|c|c|c|c|c|c|}
\hline $\begin{array}{l}\text { Characters } \\
\text { of variation } \\
\text { of }\end{array}$ & & D. F. & Leaf angle & $\begin{array}{l}\text { Chlorophyll } \\
\text { fluorescence's }\end{array}$ & $\begin{array}{l}\text { Canopy temperature } \\
\text { depression }\end{array}$ & $\begin{array}{l}\text { Chlorophyll } \\
\text { intensity }\end{array}$ & $\begin{array}{l}\text { Grain yield } \\
\text { plant-1 }\end{array}$ \\
\hline \multirow[t]{2}{*}{ GCA } & $F_{1}$ & 9 & $303.96 * *$ & $0.00 * *$ & $1.53 * *$ & $18.34 * *$ & $0.93 * *$ \\
\hline & $\mathrm{F}_{2}$ & 9 & $252.34 * *$ & $0.00 * *$ & $2.51 * *$ & $12.83^{* *}$ & $1.69 * *$ \\
\hline \multirow[t]{2}{*}{ SCA } & $F_{1}$ & 45 & $179.48 * *$ & $0.00 * *$ & $1.98 * *$ & $33.79^{* *}$ & $1.61 * *$ \\
\hline & $\mathrm{F}_{2}$ & 45 & $167.51 * *$ & $0.00 * *$ & $2.69 * *$ & $28.46^{* *}$ & $3.54 * *$ \\
\hline \multirow[t]{2}{*}{ Error } & $\mathrm{F}_{1}$ & 108 & 0.38 & 0.00 & 0.01 & 0.06 & 0.00 \\
\hline & $\mathrm{F}_{2}$ & 108 & 0.13 & 0.00 & 0.01 & 0.07 & 0.01 \\
\hline \multicolumn{8}{|l|}{$\begin{array}{l}\text { Estimated } \\
\text { variance } \\
\text { components }\end{array}$} \\
\hline \multirow[t]{2}{*}{$\sigma^{2} \mathrm{~g}$} & $F_{1}$ & & 25.30 & 0.00 & 0.13 & 1.52 & 0.08 \\
\hline & $\mathrm{F}_{2}$ & & 21.02 & 0.00 & 0.21 & 1.06 & 0.14 \\
\hline \multirow[t]{2}{*}{$\sigma^{2} s$} & $\mathrm{~F}_{1}$ & & 179.10 & 0.00 & 1.96 & 33.73 & 1.60 \\
\hline & $\mathrm{F}_{2}$ & & 167.38 & 0.00 & 2.68 & 28.38 & 3.53 \\
\hline \multirow[t]{2}{*}{$\sigma^{2} \mathrm{~g} / \sigma^{2} \mathrm{~s}$} & $\mathrm{~F}_{1}$ & & 0.141 & 0.00 & 0.066 & 0.045 & 0.05 \\
\hline & $\mathrm{F}_{2}$ & & 0.125 & 0.00 & 0.078 & 0.037 & 0.039 \\
\hline \multirow[t]{2}{*}{$\left(\sigma^{2} s / \sigma^{2} g\right)^{0.5}$} & $\mathrm{~F}_{1}$ & & 2.65 & 0.00 & 3.88 & 4.71 & 4.47 \\
\hline & $\mathrm{F}_{2}$ & & 2.82 & 0.00 & 3.57 & 5.17 & 5.02 \\
\hline
\end{tabular}

* Significance at $5 \%$ probability level, ** Significance at $1 \%$ probability level.

GCA = General combining ability; SCA = Specific combining ability

The estimated value of SCA effects for a desirable trait like chlorophyll intensity in both the generations involving combination, HUW234 x K9423, K9465 x K9351 and K9162 x K906 was favorable which a higher value of chlorophyll intensity showed a persistent green color under stress thereby, proved to be more tolerant to heat stress.

Out of 45 combinations, $25 \mathrm{~F}_{1} \mathrm{~s}$ and $22 \mathrm{~F}_{2} \mathrm{~s}$ resulted in significant SCA effects. The positive and significant SCA effect for flag leaf area of a main shoot was much effective.

In this study, the estimated values of three combinations were considerable which showed a best performance in both the generations and noted as best specific combiners i.e. K9351 x K906, K9162 x K906 and HUW234 x NW2036 over the part of increased leaf area.
The estimated value of SCA effects for specific leaf weight in K 8962 x HUW 234, K 9162 × K 906, K 9533 x K 9162, K 9465 x K 9351 and NW $2036 \times \mathrm{K} 9551$ in $\mathrm{F}_{1}$ and $\mathrm{K}$ 8962 x HUW 234, NW 2036 x K 9351, K 9465 x K 9351, K 9162 x K 906 and K 9423 x $\mathrm{K} 906$ crosses of $\mathrm{F}_{2}$ generation were most considerable; for leaf angle in K9533 x KRL210, HUW234 x NW2036, K9533 x NW2036, K9162 x K8962 and HUW324 x K9423 in $F_{1}$ and K9162 x KRL210, K9533 x NW2036, HUW324 x K9423, HUW234 x NW2036 and K8962 x KRL210 crosses of $F_{2}$ generation were most considerable which showed their superiority for producing more dry weight per unit area and per unit time proved to be more tolerant to heat stress as reported by Ashok Kumar (1995) in various crops. The performance in most of the cases of $F_{1}$ and $F_{2}$ generations indicated that the crosses K9465 x K9351, K9162 x K906, 
NW2036 x K9351, K9162 x K8962 and HUR234 x KRL210 base population due to high grain yield will be reliable for consideration in this study Similar approaches were also reported by Ahmad et al., (1978) in case of wheat.

Breeders normally vested to obtain transgressive segregants followed hybridization in order to develop a homozygous line in the self-pollinated crop. Therefore, crosses involving general combiners in respect of some characters in the present investigation may be utilized for obtaining transgressive segregants in the segregating generation or to undertake intense crossing in the early generation for getting desirable recombinants.

The possible combination for multiple parents comes under central gene pool, which supplements in the faster speed of recombination and also breaking the genetic barriers if present in such situation mass selection with concurrent random mating could be the useful breeding procedure in wheat. Based on current findings K9533, K906, K9351 and K9423 were good general combiners and K9465 x K9351, K9162 x K906, NW2036 x K9351, K9162 x K8962 and HUW234 x KRL210 were best specific combiners have better morpho-physiological traits to withstand heat stress and can be used a further breeding programme. Moreover, modified mass selection or modified pedigree method in an early generation could be most useful for developing plant ideotypes for different stress conditions.

\section{References}

Ahmad, Z.; Sharma, J.C. and Khanna, A.N. (1978). Selection parameters in relation to productivity in wheat. Abstracts $5^{\text {th }}$ Intl. wheat Genct. Symp. And Sat. Symp., New Delhi, 66-67.
Allard, R.W. and Hensche, P.E. (1964). Some parameters of population variability and their implications ink plant breeding. Adv. Agron., 16: 281-325.

Anonymous (2016-17). The $2^{\text {nd }}$ Advance Estimates of production of major crops for 2016-17 have been released by the Department of Agriculture, Cooperation and Farmers Welfare on $15^{\text {th }}$ February, 2017

Ashok Kumar (1995). Studies in growth and development parameters in relation to yield of promising wheat varieties. Thesis, M.Sc. Ag. (Agronomy). G.B. Pant University Agriculture \& Technology, Pantnagar (U.S. Nagar) $128 \mathrm{p}$.

Balouchi, H.R. (2010). Screening of wheat plants of mapping population for heat and drought tolerance, detection of wheat genetic variation. International $J$. Biol. And Life Sci., 6 (1): 56-66.

Fisher, R. A. (1918). Studies in Crop Variation. I. An Examination of the yield of dressed grain from Broadbalk. Journal of Agricultural Science. 11: 107-135.

Griffing, B. (1956 a). A generalized treatment of the use of diallel crosses in quantitative inheritance. Heredity, 10: 31-50.

Hayman, B.I. (1954a). The theory of analysis of diallel crosses II. Genetics, 43: 789809.

Hayman, B.I. (1954b). The analysis of variance of diallel tables. Biometrics, 10: $235-244$

Iqbal, M. Raja, N.I. Yasmeen, F. Hussain, M. Ejaz, M. Shah, M.A. (2017). Impacts of heat stress on wheat: A critical review. Advances in Crop Science and Technology, 5: 251. Doi: 10.4172/23298863. 1000251

Jinks, J. L. (1954). The analysis of continuous variation in a diallel cross of Nicotiana rustica varieties. Genetics, 39: 767-788. 
Kandhare, A.S., (2014). Mycotoxicc effects of seed-born fungi on seed health of black gram. Journal of Plant and Agricultural research, 1(1): 1-3

Kempthorne, O. (1957). "An Introduction to Genetical Statistics" John Wiley and Sons, Inc. New York, USA.

Mohammadi, M. and Karimizadeh, R. (2012). In sight into heat tolerance and grain yield improvement in wheat in warm rainfed regions of Iran, Crop Breeding Journal, 2 (1) : 1-8.

Shahbazi, H. Aalii, E. Seifollahi, R. and Parchehbaf, A. (2012). Physiological traits related to yield of wheat under drought stress in early, mid and late stages of grain filling. Annuals of Biological Research, 3 (6): 2947-2952.

Siddique, M., Ali, S., Malik, M. F.A. and Awan, S. I. (2004). Combining ability estimates for yield and yield components in spring wheat. Sarhad J. Agric., 20 (4): 485-487.

Singh, S.P., Singh, R.M., Singh J. and Agarwal, R.K. (1990). Combining ability for yield and some of its important components in induced mutants of bread wheat. Indian J. Genet., 50: 167-170.

Sprague, G. F. and Tatum, L.A. (1942). General vs. specific combining ability in single crosses of corn. J. Amer. Soc. Agron., 34: 923-932.

Yadav, S.P. and Murty, B.R. (1979). Genetics of semi-dwarfism in common bread wheat. Indian J. Genet., 39: 330-337.

Zahid, Akram, Ajmal, S. U., Muhammad, Munir. and Ghulam, Shabir (2008). Genetic determination of yield related attributes in bread wheat. Sarhad J. of Agric., 24 (3): 431-438.

\section{How to cite this article:}

Sanjeev Kumar, S.K. Singh, S.K. Gupta, Vishwanath, Prashant Yadav, Surendra Kumar, Jaydev Kumar, H.N. Bind and Lokendra Singh. 2017. Combining Ability in Relation to Wheat (Triticum aestivum L.) Breeding Programme under Heat Stress Environment. Int.J.Curr.Microbiol.App.Sci. 6(10): 3065-3073. doi: https://doi.org/10.20546/ijcmas.2017.610.361 